\title{
Strategi Pemasaran Pada Usaha Mikro Kecil dan Menengah Sentra Industri Kerajinan Alas Kaki Toyosima (Toyomarto Singosari Malang)
}

\author{
Rr. Nugraheni Suci Sayekti ${ }^{1}$, Bambang Agus Mulyadi², \\ Muhamad Rifa' ${ }^{3}$, Retno Ayu Dewi Novitawati ${ }^{4}$ \\ Universitas Tribhuwana Tunggadewi Malang \\ *korespondensi: rifaiunitri@gmail.com
}

Diserahkan: 22 Januari 2018, Direvisi: 23 Maret 2018, Diterima: 5 April 2018

\begin{abstract}
Increasingly tough business competition now requires entrepreneurs to determine the right business strategy to meet the market. The purpose of this research is to know the marketing strategy undertaken by the slippers, analyze the internal and external environment, and formulate the right marketing strategy for the entrepreneurs. This research is qualitative, with survey approach. The object of this research is the industrial center of sandals located in Toyomarto Village, Singosari, Malang, East Java. This research involves 35 respondents as population and research sample. From the results of the research is known that the product strategy is done by the sandal industrial center in Toyomarto village that is the product superiority, because the product produced by the entrepreneur is famous for its good quality. Pricing strategy is done by looking at the cost of production, the price given varies depending on the type of product. Distribution strategy is to directly deliver goods products to wholesale customers / distributors through sales. Promotion strategy is done by offering its products directly to distributors / distributors.
\end{abstract}

Keywords: Marketing strategy, SWOT Analysis, Toyosima

\section{abstrak}

Persaingan bisnis yang semakin ketat saat ini mengharuskan para pengusaha menentukan strategi bisnis yang tepat untuk meghadapi pasar. Tujuan penelitian ini adalah untuk mengetahui strategi pemasaran yang dilakukan oleh pengusaha sandal, menganalisis lingkungan internal dan eksternal, dan merumuskan strategi pemasaran yang tepat untuk para pengusaha. Penelitian ini berjenis kualitatif, dengan pendekatan survey. Objek penelitian ini adalah sentra industri sandal yang berlokasi di Desa Toyomarto, Singosari, Malang, Jawa Timur. Penelitian ini melibatkan 35 reponden sebagai populasi sekaligus sampel penelitian. Dari hasil penelitian diketahui bahwa strategi produk dilakukan oleh pusat industri sandal di desa Toyomarto yaitu keunggulan produknya, karena produk yang dihasilkan pengusaha terkenal dengan kualitasnya yang baik. Strategi penetapan harga dilakukan dengan melihat biaya produksi, harga yang diberikan bervariasi tergantung dari jenis produk. Strategi distribusi yang dilakukan adalah mengirimkan langsung produk-produk barang kepada pelanggan grosir / distributor melalui penjualan. Strategi promosi dilakukan dengan menawarkan produknya langsung kepada distributor / distributor.

Kata Kunci: Strategi pemasaran, Analisis SWOT, Toyosima

\section{A. PENDAHULUAN}

Indonesia termasuk salah satu negara agraris yang sebagian besar penduduknya bertempat tinggal di desa dan menggantungkan hidupnya dari sektor pertanian (Ngasifudin, M, 2017). Namun akibat dari pertumbuhan penduduk yang semakin pesat dan penyebarannya yang tidak merata menyebabkan semakin sempitnya lahan pertanian untuk bercocok tanam. Berkaitan dengan hal tersebut, maka diperlukan usaha di luar sektor pertanian yang nantinya akan mampu untuk menopang kelangsungan hidup mereka (Prasetyo, D. W, 2018). Usaha mikro, kecil dan menengah (UMKM) merupakan salah satu alternatif dalam usaha mengembangkan kesempatan kerja dan menambah penghasilan bagi masyarakat (Mutiarni, R, 2017). Selain bisa membentuk pertumbuhan ekonmi, UMKM juga dapat menyediakan lapangan pekerjaan yang menyerap tenaga kerja potensial. Kontribusi UMKM terhadap negara selalu mengalami peningkatan, hal ini dapat dilihat dari jumlah UMKM sampai saat ini sebanyak 56,5 juta unit atau 1,65 persen dari total penduduk pada kuartal kedua tahun 2014. Jumlah tersebut masih tertinggal jauh dibandingkan dengan Negara tetangga seperti Malaysia dan Singapura yang masing-masing sudah mencapai 5 dan 7 
persen, Bahkan jika dibandingkan dengan Jepang dan Amerika Serikat wirausahanya sudah mencapi 10 sampai 12 persen. Hasil yang telah diciptakan UMKM hingga saat ini mengindikasikan bahwa kontribusi UMKM terhadap negara ini sangat besar terutama dalam menyerap tenaga kerja serta pemulihan ekonomi nasional. Perkembangan UMKM di negeri ini memang cukup menjanjikan, oleh sebab itu para pengusaha kecil dan menengah harus mampu meningkatkan ketajaman visi bisnis mereka, mengingat persaingan bisnis global semakin ketat saat ini (Rohim, A., \& Kurniawan, I, 2017) yang akan berdampak pada kinerja suatu UMKM.

Keadaan ini tidak terkecuali akan dihadapi oleh Sentra industri sandal yang merupakan salah satu UMKM yang berada di Desa Toyomarto, Kecamatan Singosari, Kabupaten Malang. Sentra industri sandal ini sudah ada sejak tahun 1992 yang terletak di Dusun Sumberawan dan Ngujung Desa Toyomarto ini bisa dikatakan besar. Selain prosesnya mudah serta tersedianya bahan baku, membuat para pengrajin semangat memproduksi sandal spon dalam jumlah besar yaitu 7000 sampai 10 ribu lebih sandal berbagai jenis setiap bulannya, sebagian besar pemasarannya ke wilayah Jawa Timur, Jawa Tengah, dan Jawa Barat. Sentra industri sandal di Desa Toyomarto merupakan salah satu sektor unggulan di Kecamatan Singosari, Kabupaten Malang. Dalam menjalankan usahanya Sentra industri sandal harus mempunyai strategi yang tepat untuk kedepannya agar mampu bertahan apabila banyak mendapati permasalahan yang harus dihadapi, baik masalah internal maupun masalah eksternal yang harus diantisipasi dan diatasi oleh UMKM tersebut.

\section{B. LANDASAN TEORI}

Strategi pemasaran adalah logika pemasaran yang digunakan oleh perusahaan dengan harapan agar unit bisnis dapat mencapai tujuan perusahaan"(Kotler, 2001: 76) Menurut Tull \& Kahle (1990) yang dikutip oleh Fandy Tjiptono (2008) bahwa "Strategi pemasaran sebagai alat fundamental yang direncanakan untuk mencapai tujuan perusahaan dengan mengembangkan keungggulan bersaing yang berkesinambungan melalui pasar yang dimasuki dan program pemasaran yang digunakan untuk melayani pasar sasaran tersebut". Karena itu suatu perusahaan harus dapat memahami keinginan dan kebutuhan dari konsumen, serta mengetahui strategi-strategi pemasaran yang harus dilakukan agar dapat mencapai tujuan yang diinginkan.

Menurut Radiosunu (2001: 27), strategi pemasaran didasarkan atas lima konsep strategi berikut: (a) segmentasi pasar, yaitu tiap pasar terdiri dari bermacam-macam pembeli yang mempunyai kebutuhan, kebiasaan membeli dan reaksi yang berbeda-beda. Perusahaan tak mungkin dapat memenuhi kebutuhan semua pembeli. Karena itu perusahaan harus mengkelompokkelompokkan pasar yang bersifat heterogen ke dalam satuan-satuan pasar yang bersifat homogen; (b) market positioning, yaitu perusahaan tak mungkin dapat menguasai pasar keseluruhan. Maka prinsip strategi pemasaran kedua adalah memilih pola spesifik pemusatan pasar yang akan memberikan kesempatan maksimum kepada perusahaan untuk mendapatkan kedudukan yang kuat. Dengan kata lain perusahaan harus memilih segmen pasar yang dapat menghasilkan penjualan dan laba yang paling besar; (c) targeting, yaitu strategi memasuki segmen pasar yang dijadikan sasaran penjualan; (d) marketing mix strategy, yaitu Kumpulan variabel-variabel yang dapat digunakan perusahaan untuk mempengaruhi tanggapan konsumen. Variabel-variabel yang dapat mempengaruhi pembeli adalah variabelvariabel yang berhubungan dengan product, place, promotion dan price (4P); dan (d) timming strategy yaitu penentuan saat yang tepat dalam memasarkan produk merupakan hal ini harus diperhatikan oleh perusahaan.

Berdasarkan SK Menteri Negara Koperasi dan UMKM No: 32 / Kep / M.KUMKM / IV / 2002, tentang Pedoman Penumbuhan dan Pengembangan Sentra. Sentra didefinisikan sebagai pusat kegiatan di kawasan/lokasi tertentu dimana terdapat usaha yang menggunakan 
bahan baku/sarana yang sama, menghasilkan produk yang sama/sejenis serta memiliki prospek untuk dikembangkan menjadi klaster.

Sentra merupakan unit kecil kawasan yang memilik ciri tertentu dimana didalamnya terdapat kegiatan proses produksi dan merupakan area yang lebih khusus untuk suatu komoditi kegiatan ekonomi yang telah terbentuk secara alami yang ditunjang oleh sarana untuk berkembangnya produk atau jasa yang terdiri dari sekumpulan pengusaha mikro, kecil dan menengah. Di area sentra tersebut terdapat kesatuan fungsional secara fisik : lahan, geografis, infrastruktur, kelembagaan dan sumberdaya manusia, yang berpotensi untuk berkembangnya kegiatan ekonomi dibawah pengaruh pasar dari suatu produk yang mempunyai nilai jual dan daya saing tinggi. Pengertian industri kecil Menurut Undangundang No. 9 Tahun 1995 tentang Usaha Kecil, definisi industri kecil adalah kegiatan ekonomi rakyat yang memiliki hasil penjualan tahunan maksimal Rp 1 milyar dan memiliki kekayaan bersih, tidak termasuk tanah dan bangunan tempat usaha, paling banyak Rp200 juta (Sudisman \& Sari, 2008: 5).

Industri kecil dan kerajinan rumah tangga di Indonesia, berdasarkan eksistensi dinamisnya dapat dibagi dalam tiga kategori, yaitu: (a) Industri lokal, yaitu kelompok industri yang menggantungkan kelangsungan hidupnya pada pasar setempat yang terbatas serta relatif tersebar dari segi lokasinya. Pada umumnya skala usaha kelompok ini sangat mencerminkan suatu pola perusahaan yang sistematis. Pemasaran yang sangat terbatas telah menyebabkan kelompok ini pada umumnya menggunakan transportasi yang sangat sederhana dan jasa pelayanan perantara bisa dikatakan kurang menonjol; (b) Industri sentra, yaitu kelompok industri yang dari segi satuan usaha mempunyai skala kecil tetapi membentuk suatu pengelompokan atau kawasan produksi yang terdiri dari kumpulan usaha yang sejenis. Dari segi pemasarannya kelompok ini umumnya menjangkau pasar yang lebih luas dan peran pedagang perantara/ pedagang pengumpul menjadi cukup menonjol; dan (c) Industri mandiri, yaitu kelompok industri yang masih mempunyai sifat-sifat industri kecil, namun telah berkemampuan mengadaptasi teknologi produksi yang cukup canggih.

Pemasaran hasil produksi tidak tergantung pada pedagang perantara dan tenaga kerja yang diserap hanya sedikit. Sedangkan menurut Badan Pusat Statistik, klasifikasi industri dibedakan menjadi (BPS, 2010): (a) Industri rumah tangga, yaitu industri dengan jumlah tenaga kerja antara 1-4 orang; (b) Industri kecil, yaitu industri dengan jumlah tenaga kerja antara 5-19 orang; (c) Industri sedang, yaitu industri dengan jumlah tenaga kerja antara 20-99 orang; dan (d) Industri besar, yaitu industri dengan jumlah tenaga kerja lebih dari 100 orang.

\section{METODE PENELITIAN}

Berdasarkan permasalahan yang diteliti, maka jenis penelitian ini adalah penelitian kualitatif dengan pendekatan survey. Menurut Moleong (2007:6) Penelitian kualitatif adalah penelitian yang bermaksud untuk memahami fenomena tentang apa yang dialami oleh subjek penelitian misalnya perilaku, persepsi, motivasi, tindakan, secara holistik, dan dengan cara deskripsi dalam bentuk kata-kata dan bahasa, pada suatu konteks khusus yang alamiah dan dengan memanfaatkan berbagai metode alamiah. Populasi dalam penelitian ini adalah para pengusaha/pengrajin alas kaki di desa Toyomarto, Malang sejumlah 35 pengrajin. Sampel yang diambil dalam penelitian ini adalah seluruh populasi yaitu 35 orang pengrajin. Data yang digunakan adalah data primer yang diperoleh melalui wawancara. Selain itu, penelitian ini juga dilengkapi dengan data sekunder untuk menunjang penelitian.

\section{HASIL DAN PEMBAHASAN}

Desa Toyomarto Kecamatan Singosari Kabupaten Malang dengan berbagai potensi daerah yang bernilai ekonomis serta potensi pariwisata yang dapat dikembangkan. Dari semua kegiatan ekonomi masyarakatnya yang telah berjalan lama, tersimpan nilai lebih yang 
dapat digunakan untuk memperbaiki kondisi perekonomian dan juga melestarikan budaya yang ada. Tidak hanya terkenal dengan warisan budaya sejarah berupa candi yang masuk didalam area Desa Toyomarto, tapi di Desa Toyomarto juga di kenal sebagai pengusaha sandal spon dan klompen. Persaingan yang ketat saat ini membuat pelaku usaha/perusahaan harus menggunakan strategi-strategi pemasaran yang benar-benar tepat untuk mencapai tujuan yang telah ditetapkan atau untuk mempertahankan kelangsungan hidupnya. Tujuan kegiatan pemasaran disini adalah untuk mempengaruhi konsumen agar bersedia membeli barang atau jasa yang dihasilkan perusahaan di saat mereka membutuhkan. Karena itu suatu perusahaan harus dapat memahami keinginan dan kebutuhan dari konsumen, serta mengetahui strategi-strategi pemasaran yang harus dilakukan agar dapat mencapai tujuan yang diinginkan.

Hal ini tentunya juga akan dihadapi oleh para pengusaha sandal di desa Toyomarto agar produk yang dihasilkan dapat bersaing di pasaran, karena dalam mendirikan sebuah usaha tidak akan lepas dari kendala yang muncul dari dalam ataupun dari luar. Sehingga dalam hal ini perlu tentunya menganalisis faktor- faktor lingkungan intrenal dan lingkungan eksternal dari pengusaha sandal di Desa Toyomarto. Pengusaha sandal di Desa Toyomarto terbagi di dua Dusun yaitu Dusun Ngujung dan Dusun Sumberawan. Data pelaku usaha tersebut dapat dilihat pada tabel berikut:

Tabel 1 Data pengusaha sandal di Desa Toyomarto

\begin{tabular}{|c|c|c|c|c|c|}
\hline \multicolumn{3}{|c|}{ Dusun seumber awan } & \multicolumn{3}{|c|}{ Dusun ngujung } \\
\hline NO. & NAMA & ALAMAT & NO. & NAMA & ALAMAT \\
\hline 1. & Yono & Rt 01 & 1. & Kodir & Rt 01 \\
\hline 2. & Ansori & Rt 01 & 2. & Yusup & Rt 01 \\
\hline 3. & Cahyono & Rt 01 & 3. & Suyono & Rt 02 \\
\hline 4. & H. toha & Rt 01 & 4. & Mulyadi & Rt 03 \\
\hline 5. & Sumardi & Rt 01 & 5. & Sugiyanto & Rt 04 \\
\hline 6. & H. sofyan & Rt 01 & 6. & Riyadi & Rt 05 \\
\hline 7. & Buhori & Rt 02 & 7. & H. mat & Rt 05 \\
\hline 8. & Supri & Rt 03 & 8. & Samsuri & Rt 06 \\
\hline 9. & Ali & Rt 03 & 9. & Sumardi & Rt 07 \\
\hline 10. & H. as'ari & Rt 03 & 10. & Khoirul & Rt 07 \\
\hline 11. & Didik & Rt 03 & 11. & Suadi & Rt 07 \\
\hline 12. & Cipto & Rt 04 & 12. & Robul & Rt 07 \\
\hline 13. & Mukamad & Rt 04 & 13. & Suyanto & Rt 07 \\
\hline 14. & H. sukiri & Rt 04 & 14. & Prayit & Rt 07 \\
\hline 15. & Nasir & Rt 05 & 15. & Majari & Rt 07 \\
\hline 16. & H. imam & Rt 06 & 16. & Suaji & Rt 07 \\
\hline 17. & Supri & Rt 06 & 17. & Hartono & Rt 08 \\
\hline 18. & Wira'i & Rt 07 & & & \\
\hline
\end{tabular}

Sumber : Data primer diolah 2016

Dari data yang di dapat bahwa pengusaha sandal di Desa Toyomarto yang masih aktif sampai saat ini secara keseluruhan hanya berjumlah 35 pengusaha yang selebihnya sudah tidak memproduksi lagi.

\section{Analisis Faktor Lingkungan Internal}

Dalam pembahasan analisis lingkungan internal maka dapat dipahami beberapa faktor yang menjadi perhatian berkaitan kekuatan dan kelemahan pada sentra industri sandal di desa toyomarto, beberapa faktor tersebut antara lain:

\section{Sumber Daya Manusia}

Sumber daya manusia menjadi pemegang peranan penting untuk menjalankan usaha, Apalagi sebagai pengusaha tentunya harus dapat membaca peluang dan tantangan pasar serta kelemahan dan kelebihan dari perusahaan agar dapat diterima dan bersaing dengan 
perusahaan sejenis. Para pengusaha sandal di desa Toyomarto yang sudah dikenal sejak dulu memang terkenal dengan kualitas produk sandalnya baik. Untuk masalah sumber daya manusia para pengusaha tidak perlu repot-repot mencari karena rata-rata semua warga di dusun sumber awan dan dusun ngujung sudah mempunyai keahlian dalam membuat sandal yang mempunyai kualitas baik. Bahkan anak yang masih duduk di bangku SD sudah mahir dalam membuat sandal, karena memang setiap hari hidup dilingkungan pengusaha sandal. Tapi untuk sekarang ini sudah makin sulit dalam mencari karyawan, ini diakibatkan oleh banyaknya pabrik-pabrik yang berdiri di daerah sekitar desa Toyomarto sehingga banyak warga desa Toyomarto bekerja di pabrik. Ini mengakibatkan para pengusaha pemula kesulitan dalam mecari karyawan dan menjalankan usahanaya.

Pengelolaan sumber daya manusia dilakukan oleh si pemilik sendiri, Perekrutan dilakukan dengan pemberitahuan secara langsung oleh pemilik kepada masyarakat di sekitar rumah produksi. Jumlah sumber daya manusia yang dimiliki hanya berjumlah 5-7 orang, jadwal kerja karyawan mulai hari Senin sampai Sabtu, dengan rata-rata jam kerja mulai pukul 08.00 -20.00 WIB. Para karyawan juga mendapatkan makan 3 kali sehari. Sistem gaji yang digunakan adalah sistem borongan 1 kodi dihargai Rp.6000 dalam 1 kodi berisi 20 pasang sandal, rata-rata para karyawan dalam 1 hari bisa menghasilkan 5 kodi dalam sehari yang berarti 1 orang bisa menghasilkan 100 pasang sandal dalam 1 hari itu untuk produk sandal yang prosesnya rumit. Sedangkan untuk sandal yang yang tidak rumit prosesnya 1 orang bisa menghasilkan 10 kodi dalam 1 hari yang berarti 1 orang bisa menghasilkan 200 pasang sandal dalam 1 hari, jadi rata-rata para pengusaha menghasilkan 400 -500 pasang sandal dalam 1 hari.

2. Terbatasnya modal

Permodalan merupakan faktor utama yang diperlukan untuk mengembangkan suatu unit usaha. Pada umumnya usaha kecil dan menengah merupakan usaha perorangan atau perusahaan yang sifatnya tertutup, yang hanya mengandalkan pada modal dari si pemilik usaha yang jumlahnya sangat terbatas. Para pengusaha sandal di desa Toyomarto dalam memulai usahanya hanya mengandalkan modal sendiri yang jumlahnya terbatas, menurut para pengusaha dulu memang pernah ada koperasi yang menangani dalam memberikan modal tapi itu tidak sampai 1 tahun. Karena makin bertambahnya pengusaha dan mereka saling berebut untuk mendapatkan modal, akhirnya koperasi yang menangani para pengusaha tidak mampu untuk memberikan modal. Berdasarkan hasil wawancara dapat diketahui alasan para pengusaha tidak mau meminjam modal dari bank yaitu karena iklim usaha yang tidak menentu dan takut usahanya nanti tidak berkembang karena memang persaingan harga yang semakin ketat. Sehingga para pengusaha tidak mau mengambil resiko dan memlih lebih baik menggunakan modal sendiri meskipun terbatas. Para pengusaha sandal di desa Toyomarto memulai usahanya dari bawah mereka merintis sedikit demi sedikit bahkan hanya ada yang bermodal nekad saja, tapi rat-rata mereka sekarang usahanya sukses dan berkembang bahkan ada salah satu pengusaha yang sudah bisa membeli rumah dari hasil usahanya.

3. Peralatan yang masih sederhana

Peralatan yang digunakan oleh pengusaha sandal masih sederhana yang masih seutuhnya mengandalkan tenaga manusia, Kendala utama pengusaha tidak mengadopsi teknologi yang lebih maju adalah kurangnya modal yang hanya mengandalkan modal sendiri yang jumlahnya terbatas. Memang semua pengusaha sandal di desa Toyomarto menggunakan peralatan yang masih sederhana dalam membuat memproduksi sandal, tapi dengan kemampuan mereka yang sudah puluhan tahun menjalalani usaha dalam memproduksi sandal menjadikan kualitas sandal yang dihasilkan tidak kalah dengan yang menggunakan mesin, mungkin hanya kalah dalam jumlah produksi yang otomoatis produksi menggunakan mesin lebih cepat dari pada tenaga manual. 


\section{Tempat produksi}

Para pengusaha sandal di desa Toyomarto rata-rata dalam memproduksi sandal hanya memanfaatkan ruang keluarga sebagai tempat produksinya, hanya ada beberapa pengusaha yang mempunyai tempat khusus untuk kegiatan produksinya. Sehingga setiap rumah pengusaha sandal banyak bahan baku yang berserakan di halaman ruamhnya, sedangkan diruang tamu di penuhi dengan tumpukan sandal-sandal baik itu yang sudah jadi ataupun yang baru selesai dicetak.

5. Hubungan yang baik dengan pemasok bahan baku

Bahan baku untuk memproduksi sandal di dapatkan dari pemasok yang ada di desa Toyomarto memang ada beberapa toko yang memang khusus menjual bahan baku untuk pembuatan sandal spon. Ada sekitar 4 toko yang memang khusus menyediakan bahan baku bagi para pengusaha, semua yang dibutuhkan para pengusaha ada dari bahan dasar seperti spon, tali sandal serta pemesanan desain para pengusaha langsung ke pemasok bahan baku. Hal ini memudahkan para pengusaha untuk mendapatkan sehingga mereka tidak usah langsung ke surabaya, memang dari segi harga lebih mahal sedikit tapi para pengusaha mengaku senang dengan adanya toko yang menjual bahan baku. Bukan hanya itu saja hubungan para pengusaha dengan pemasok bahan baku yang hanya berlandaskan sistem kepercayaan, sehingga mereka dapat berhutang dulu kalau tidak uang untuk mendapatkan bahan baku.

6. Pemasaran produk

Sebagian besar produk sandal yang dihasilkan oleh para pengusaha sandal di desa Toyomarto dipasarkan melalui grosir yang ada di wilayah jawa timur. Tapi sekarang para pengusaha lebih banyak memasarkan produknya ke jawa tengah dan jawa barat, itu dikarenakan pasar yang lebih potensial dari pada di jawa timur. Para pengusaha mengaku untuk wilayah jawa timur sudah kurang potensial itu dikarenakan persaingan harga yang semakin ketat, sehingga mengakibatkan harga jual produk yang semakin turun. Harga jual produk sandal yang ditetapkan pihak pengusaha bervariasi, tergantung dari jenis dan model sandal yang dipesan, untuk produk sandal yang biasa harganya antara Rp.120.000Rp.150.000, untuk sandal yang tebal Rp.300.000-Rp.350.000, sedangkan untuk sandal gunung Rp.500.000-Rp.600.000, per kodi ( 1 kodi $=20$ pasang sepatu).

\section{Analisis Faktor Lingkungan Eksternal}

Hasil kajian analisis lingkungan eksternal pada sentra industri sandal di desa toyomarto singosari malalang Menujukkan beberapa faktor peluang sekaligus tantangan yang harus dihadapi oleh para pelaku usaha, adapun hasil analiis faktor lingkungan eksternal meliputi:

\section{Persaingan}

Dengan situasi seperti sekarang ini maka banyak para pengusaha ingin mempertahankan diri dan merebut perhatian konsumen, sehingga persaingan tidak mungkin terhindarkan. Hanya pengusaha yang mampu mengikuti selera konsumen dan mempunyai inovasi yang mampu bertahan. Persaingan yang di hadapi para pengusaha sandal di desa toyomarto yaitu persaingan antara sesama pengusaha sandal yang ada di desa toyomarto, para pengusaha mengaku terjadi persaingan yang tidak sehat antara sesama pengusaha sandal dimana para pengusaha sandal saling menjatuhkan satu sama lain dengan cara mempermainkan harga jual agar produknya lebih laku di pasaran. Selain itu banyaknya pesaing baru yang muncul dengan persaingan harga yang semakin ketat terutama produsen sandal dari surabaya merupakan ancaman yang harus di waspadai oleh para pengusaha sandal di desa toyomarto.

2. Harga bahan baku yang tidak menentu 
Harga bahan baku sangat berpengaruh terhadap biaya produksi para pengusaha sandal di desa Toyomarto, harga bahan baku yang tidak menentu membuat para pengusaha harus pintar dalam mengatur keuangan mereka agar usahanya tetap berjalan. Para pengusaha mengaku bahwa kenaikan harga bahan baku tidak berpengaruh pada harga jual produknya, kondisi ini membuat para pengusaha harus mempunyai strategi yang tepat agar dapat bertahan dalam keadaan yang semakin tidak menentu.

3. Demografi

Dapat diketahui bahwa jumlah penduduk dan jumlah usia produktif selalu semakin meningkat dari tahun ke tahun. Hal ini akan menjadi prospek bagi pengusaha sandal di desa toyomarto karena produk yang di hasilkan bermacam-macam dari sandal untuk anakanak sampai sandal untuk orang tua.

4. Kemajuan tekhnologi

Dengan adanya beraneka ragam tekhnologi yang ada seperti saat ini, seharusnya para pengusaha bisa memanfaatkan tekhnologi itu secara maksimal. Tapi para pengusaha sandal di desa toyomarto belum menggunakan teknologi modern dalam memproduksi sandal, ini akibat dari keterbatasan modal yang hanya mengandalkan modal dari si pemilik usaha yang jumlahnya sangat terbatas, hail ini berdampak pada peralatan yang digunakan untuk proses produksi masih bersifat manual.

5. Peran pemerintah

Peran pemerintah dalam mendukung pembiayaan usaha kecil menengah (UMKM) sangatlah penting, saat ini sudah banyak program pemerintah yang memang disediakan bagi para pelaku UMKM dengan syarat-syarat yang tidak memberatkan seperti Lembaga Keuangan Mikro bank antara Lain: BRI unit Desa dan Bank Perkreditan Rakyat (BPR) Sampai saat ini BRI memiliki sekitar 4.000 unit yang tersebar diseluruh Indonesia dan program KUR (kredit usaha rakyat). Program ini memang disediakan bagi pelaku para pelaku UMKM yang mempunyai masalah dengan permodalan agar dapat mengembangkan usahanya

\section{Analisis SWOT}

Berdasarkan hasil kajian dari faktor lingkungan internal dan eksternal, maka selajutnya dilakukan analisis SWOT yang dari hasil analisis yang telah dilakukan dapat dihasilkan pemahaman tentang kondisi usaha yang dilakukan pada sentra indsutri sandal di desa toyomarto adalah sebagaimana dilihat pada tabel berikut:

Tabel 2. Matrik Analisis SWOT

\begin{tabular}{|c|c|c|}
\hline EFAS & $\begin{array}{l}\text { S (strenght) } \\
\text { 1. Memiliki SDM yang sangat } \\
\text { baik. } \\
\text { 2. Bahan baku yang sudah } \\
\text { tersedia } \\
\text { 3. Mempunyai kualitas produk } \\
\text { yang baik } \\
\text { 4. Memiliki pelanggan tetap } \\
\text { 5. Hubungan baik dengan } \\
\text { pemasok bahan baku }\end{array}$ & $\begin{array}{l}\text { W (weaknes) } \\
\text { 1. Peralatan yang digunakan } \\
\text { masih manual } \\
\text { 2. Tempat produksi yang kurang } \\
\text { memadai } \\
\text { 3. Modal usaha yang dimiliki } \\
\text { terbatas }\end{array}$ \\
\hline $\begin{array}{l}\text { O (oppurtunity) } \\
\text { 1. Pertumbuhan penduduk. } \\
\text { 2. Kemampuan berinovasi } \\
\text { mengikuti selera } \\
\text { konsumen } \\
\text { 3. Kemajuan teknologi } \\
\text { 4. Perubahan pola dan gaya } \\
\text { hidup masyarakat } \\
\text { 5. Peran pemerintah }\end{array}$ & $\begin{array}{l}\text { Strategi SO } \\
\text { 1. } \begin{array}{l}\text { Menciptakan variasi produk } \\
\text { berdasarkan trend pasar ( } \mathrm{S} 1,\end{array} \\
\mathrm{~S} 2, \mathrm{~S} 3, \mathrm{O} 1, \mathrm{O} 2, \mathrm{O} 4) \\
\text { 2. } \begin{array}{l}\text { Mempertahankan kualitas } \\
\text { produk ( S1, S3, S4, O1, O4 ) }\end{array}\end{array}$ & $\begin{array}{l}\text { Strategi WO } \\
\text { 1. Memanfaatkan lembaga } \\
\text { perbankan untuk meningkatkan } \\
\text { modal usaha dan } \\
\text { mengembangkan usahanya } \\
\text { W1, W2, W3, O5) } \\
\text { 2. Memanfaatkan kemajuan } \\
\text { teknologi untuk meningkatkan } \\
\text { mutu dan nilai jual produk ( } \\
\text { W1, W3, O3, O5) }\end{array}$ \\
\hline
\end{tabular}




\begin{tabular}{|c|c|c|}
\hline T (threats) & Strategi ST & Strategi WT \\
\hline $\begin{array}{l}\text { 1. Kurs rupiah yang tidak } \\
\text { menentu } \\
\text { mempengaruhi } \\
\text { baku }\end{array}$ & $\begin{array}{l}\text { 1. Meningkatkan kualitas } \\
\text { pelayanan terhadap pelanggan ( } \\
\mathrm{S} 4, \mathrm{~T} 2, \mathrm{~T} 3) \\
\text { 2. }\end{array}$ & $\begin{array}{l}\text { 1. Menambah modal dengan } \\
\text { melakukan pinjaman ke } \\
\text { lembaga perbankan ( } \mathrm{W} 1, \mathrm{~W} 2 \text {, } \\
\text { W3 T1 ) }\end{array}$ \\
\hline $\begin{array}{l}\text { 2. Persaingan yang tidak } \\
\text { sehat antara sesama } \\
\text { pengusaha yang ada di } \\
\text { desa Toyomarto } \\
\text { 3. Banyaknya pesaing baru } \\
\text { dengan persaingan harga } \\
\text { yang semakin ketat. }\end{array}$ & $\begin{array}{l}\text { produk agar lebih menarik } \\
\text { konsumen }(\mathrm{S} 1, \mathrm{~S} 2, \mathrm{~S} 3, \mathrm{~T} 2, \mathrm{~T} 3)\end{array}$ & $\begin{array}{ll}\text { 2. } & \text { Menawarkan harga yang } \\
\text { bersaing }(\mathrm{W} 1, \mathrm{~T} 2, \mathrm{~T} 3) & \end{array}$ \\
\hline
\end{tabular}

Sumber: Data primer, diolah (2016)

Berdasarkan tabel matrik SWOT yang telah dilakukan di atas maka dapat diberikan penjelaskan sebagai berikut:

a. Kekuatan (strenght)

Pertama Memiliki SDM yang sangat baik. Sumber daya manusia merupakan faktor yang sangat penting dalam menjalankan sebuah usaha, karena akan berpengaruh pada kualitas produk yang dihasilkan. Pengusaha sandal di desa Toyomarto memilki sumber daya manusia yang sangat baik, karena memang usaha sandal ini merupakan usaha turuntemurun yang sudah menjadi sumber penghasilan utama khususnya warga yang ada di dusun Sumber awan dan dusun Ngujung. Sehingga rata-rata warga yang ada di dusun Sumber awan dan dusun Ngujung sudah ahli dalam membuat sandal, bahkan anak yang masih duduk dibangku SD sudah terampi dalam membuat sandal. Kedua, Bahan baku yang sudah tersedia. Bahan baku dalam pembuatan sandal di beli dari kota Surabaya, tapi sekarang para pengusaha sudah tidak perlu lagi ke Surabaya untuk mendapatkan bahan baku, karena di desa Toyomarto sudah ada beberapa toko yang menjadi pemasok bahan baku. Ketiga mempunyai kualitas produk yang baik. Kualitas produk merupakan faktor yang menentukan keunggulan bersaing suatu produk dipasaran. Produk yang dihasilkan para pengusaha sandal di desa Toymarto memilki kualitas yang baik, ini ditunjang dengan pengalaman para pengusaha yang sudah puluhan tahun menggeluti usaha ini. Keempat memliki pelanggan tetap. Dalam memasarkan produknya para pengusaha sandal di desa Toyomarto langsung mendatangi grosir - grosir sandal yang ada di wilayah Jawa Timur, Jawa Tengah, dan Jawa Barat. Staregi ini sudah dilakukan para pengusaha sejak dulu dan memang sudah terbukti efektif, karena sekarang setiap pengusaha sudah memilki pelanggan tetap. Dan kelima hubungan baik dengan pemasok bahan baku. Para pengusaha sandal di desa Toyomarto memilki hubungan baik dengan pemasok bahan baku yang hanya berlandaskan sistem kepercayaan. Para pengusaha dapat mengambil bahan baku dulu tanpa membayar, hal ini tentunya sangat membantu bagi para pengusaha yang mempunyai modal terbatas.

\section{b. Kelemahan (weaknes)}

Permata, Peralatan yang digunakan masih manual. Peralatan yang digunakan pengusaha sandal di desa toyomarto dalam memproduksi sandal masih sederhana yang masih mengandalkan tenaga manusia. Ini dikarenakan keterbatasan modal yang dimilki para pengusaha sehingga berdampak pada alat produksi yang digunakan. Kedua, tempat produksi yang kurang memadai. Tempat produksi yang digunakan oleh para pengusaha sandal di desa Toyomarto hanya memanfaatkan ruang keluarga, tidak ada tempat khusus dalam memproduksi sandal. Ketiga, Modal usaha yang dimiliki terbatas. Modal yang digunakan oleh para pengusaha merupakan modal sendiri yang jumlahnya sangat terbatas, 
dengan keterbatasan modal yang dimilki tentunya akan berdampak pada proses produksi seperti alat produksi yang digunakan.

\section{c. Peluang (oppurtunity)}

Pertama, pertumbuhan penduduk. Pertumbuhan penduduk yang semakin meningkat merupakan peluang bagi para pengusaha sandal, hal ini tentunya menjadi prospek kedepannya agar usahanya tetap berjalan. Kedua, kemampuan berinovasi mengikuti selera konsumen. Dengan persaingan bisnis yang semakin ketat seperti sekarang ini para pengusaha di tuntut untuk dapat berinovasi mengikuti selera konsumen agar dapat bertahan. Begitu pula dengan pengusaha sandal di desa Toyomarto yang harus mampu berinovasi agar produknya tidak kalah bersaing dengan produk pesaing. Ketiga, kemajuan teknologi. Perkembangan teknologi yang semakin pesat dan semakin canggih seperti sekarang ini, seharusnya bisa dimanfaatkan oleh pengusaha sandal di desa Toyomarto untuk meningkatkan proses produksinya. Keempat, Perubahan pola dan gaya hidup masyarakat. Perkembangan pola dan gaya hidup masyarakat saat ini yang cepat tentunya bisa dimanfaatkan oleh pengusaha sandal di desa Toyomarto, tentunya para pengusaha harus tau trend pasar saat ini agar tidak kalah bersaing dengan pengusaha dari daerah lain, dan kelima peran pemerintah. Peran pemerintah sangatlah penting bagi para pelaku UMKM, sekarang sudah ada program pemerintah untuk mendukung pembiayaan usaha kecil menegah dengan syarat-syarat yang tidak memberatkan seperti Lembaga Keuangan Mikro bank antara Lain: BRI unit Desa dan Bank Perkreditan Rakyat (BPR) dan Kredit Usaha Rakyat (KUR). Seharusnya ini bisa dimanfaatkan oleh pengusaha sandal di desa Toyomarto yang hanya mengandalkan modal sendiri yang jumlahnya sangat terbatas.

\section{d. Ancaman (threats)}

Pertama, Kurs rupiah yang tidak menentu sehingga mempengaruhi bahan baku. Harga bahan baku yang tidak menentu tentunya akan berpengaruh pada biaya produksi, sehingga para pengusaha harus mempunyai startegi yang tepat dalam menghadapi situasi seperti ini agar usahanya tetap bertahan. Kedua, persaingan yang tidak sehat antara sesama pengusaha yang ada di desa Toyomarto. Persaingan yang terjadi bukan hanya dengan produsen sandal dari daerah lain, tetapi antara sesama pengusaha sandal yang ada di desa Toyomarto terjadi persaingan yang tidak sehat, yaitu dengan cara saling menjatuhkan harga jual sandal di pasaran. Ketiga, banyaknya pesaing baru dengan persaingan harga yang semakin ketat. Banyaknya pesaing baru yang muncul membuat para pengusaha sandal di desa Toyomarto harus berpikir keras agar produknya tetap bertahan. Tentu ini menjadi ancaman sehingga para pengusaha harus mempunyai strategi untuk manghadapi para pesaing dengan persaingan harga yang semakin ketat.

\section{E. PENUTUP}

Berdasarkan pembahasan yang telah diuraikan maka dapat ditarik kesimpulan strategi bauran pemasaran yang dilakukan pengusaha sentra industri sandal di Desa Toyomarto sebagai berikut: (1) Strategi produk yang dilakukan sentra industri sandal di Desa Toyomarto yaitu dengan keunggulan produk yang dimilikinya, karena produk yang dihasilkan pengusaha sandal di Desa Toyomarto terkenal dengan kualitasnya yang baik; (2) Strategi harga yang dilakukan sentra industri sandal di Desa Toyomarto yaitu dengan melihat besarnya biaya produksi harga yang diberikan bervariasi tergantung pada jenis produknya antara Rp.120.000-Rp.600.000 per kodi; (3) Strategi distribusi yang dilakukan sentra industri sandal di Desa Toyomarto yaitu dengan mengantarkan langsung barang hasil produksinya ke grosirgrosir langganannya melalui sales yang ada di wilayah Jawa Timur, Jawa Tengah dan Jawa Barat; dan (4) Strategi promosi yang dilakukan sentra industri sandal di Desa Toyomarto 
yaitu dengan menawarkan langsung hasil produknya ke grosir-grosir yang ada di wilayah Jawa Timur, Jawa Tengah dan Jawa Barat.

\section{DAFTAR PUSTAKA}

Badan pusat statistik.pertumbuhan UMKM di indonesia .http://www.Suarapembaruan.com/index.php.

Tjiptono, F., Chandra, G., \& Adriana, D. (2008). Pemasaran strategik. Yogyakarta: Andi.

Kotler, Philip dan Gary Amstrong.2001. Marketing, Terjemahan: Herujati, Jilid I Cetakan Kesepuluh. Jakarta: Penerbit Erlangga.

Moleong, J. Lexy. 2007. Metodologi penelitian kualitatif.

Mutiarni, R. (2017). Implementasi Electronic Data Processing Pada Koperasi Wanita. Eksis: Jurnal Riset Ekonomi dan Bisnis, 12(2 Okt), 135-148.

Prasetyo, D. W. (2018). Pembinaan Usaha Kecil Mikro dan Menengah (UMKM) Konveksi Desa Karobelah Kecamatan Mojoagung-Jombang. Comvice: Journal Of Community Service, 2(1), 9-14.

Radiosuno, 2001. Konsep, sistem, dan konsep pemasaran, FE-UGM, Yogyakarta.

Rohim, A., \& Kurniawan, I. (2017). Manajemen Usaha Dan Produksi Pada Usaha Mikro, Kecil Dan Menengah (UMKM) Di Desa Carang Wulung Wonosalam. Comvice: Journal Of Community Service, 1(1), 23-28.

Sudisman, U., \& Sari, A. (2008). Undang-Undang Usaha kecil 1995 dan Peraturan Perkoperasian. Jakarta: Mitrainfo.

Tull, D. S., \& Kahle, L. R. (1990). Marketing management. New York, NY.: Macmillan. 